Vol. 4 No. 1 (2021) : $28-37$

Available online at http://jurnal.unissula.ac.id/index.php/fikri/issue/archive

\title{
INTERNALISASI NILAI-NILAI BUDAYA RELIGIUS MELALUI KEGIATAN KEAGAMAAN DI MTSN 3 PONOROGO
}

\author{
Septia Nur Wahidah', Muhammad Heriyudanta ${ }^{2}$ \\ ${ }^{1}$ IAIN Ponorogo, Jawa Tengah \\ Email: septinurwahidah@gmail.com ${ }^{1}$ yudanta10@gmail.com²
}

\begin{abstract}
The provision of general and religious education materials must be in harmony with each other, an imbalance in the provision of religious material will result in the loss of internal values in students. For this reason, planting and cultivating religious material at various levels of education is a must in the midst of rapid advances in science and technology. This study aims to determine the internalization of religious cultural values through religious activities at MTsN 3 Ponorogo, to determine the factors supporting and inhibiting the internalization of religious cultural values through religious activities at MTsN 3 Ponorogo, to determine the contribution of internalization of religious cultural values through religious activities. religion at MTsN 3 Ponorogo. This research uses a qualitative approach with the type of case study research. Data collection techniques using the method of observation, interviews, and documentation. Meanwhile, the data analysis technique uses the model analysis by Miles and Huberman with the following steps: data analysis, data reduction, data presentation, and drawing conclusions or verification. From the internalization of religious cultural values at MTsN 3 Ponorogo through religious activities, it can be seen that religious activities have been going well by paying attention to various aspects of students, the inhibiting factors are the culture of globalization, the influence of friends and the lack of religious education from parents. While the supporting factors are support from parents and all teachers at MTsN 3 Ponorogo, as well as the presence of students who are good in terms of worship can be a reflection for other students, and have an effect on increasing the discipline and awareness of students in worship, and social attitude and harmony in society.
\end{abstract}

Key Word: Religious Cultural Values, Religious Activities

\begin{abstract}
Abstrak
Penelitian ini bertujuan untuk 1) mengetahui internalisasi nilai-nilai budaya religius melalui kegiatan keagamaan di MTsN 3 Ponorogo 2) untuk mengetahui faktor pendukung dan penghambat internalisasi nilai-nilai budaya religius melalui kegiatan keagamaan di MTsN 3 Ponorogo 3) untuk mengetahui kontribusi internalisasi nilai-nilai budaya religius melalui kegiatan keagamaan di MTsN 3 Ponorogo. Penelitian ini menggunakan pendekatan kualitatif dengan jenis penelitian studi kasus. Teknik pengumpulan data dengan menggunakan metode observasi, wawancara, dan dokumentasi. Sedangkan teknik analisis data menggunakan analisis model Miles dan Huberman dengan langkah-langkah: analisis data, reduksi data, penyajian data, dan penarikan kesimpulan atau verifikasi. Hasil penelitian ini menunjukkan bahwa internalisasi nilai-nilai budaya religius di MTsN 3 Ponorogo melalui kegiatan keagamaan dapat berjalan dengan baik. Faktor penghambatnya adalah budaya globalisasi, pengaruh dari teman serta kurangnya pendidikan agama dari orang tua. Sedangkan faktor pendukungnya yaitu dukungan dari pihak orang tua dan semua guru di MTsN 3 Ponorogo, serta adanya peserta didik yang sudah baik dari segi ibadah dapat menjadi cerminan bagi peserta didik yang lainnya, serta berpengaruh dalam meningkatkan kedisiplinan dan kesadaran peserta didik dalam beribadah, serta sikap sosial dan kerukunan di masyarakat.
\end{abstract}

Kata Kunci: Nilai Budaya Religius, Kegiatan Keagamaan

\section{Pendahuluan}


Pendidikan merupakan hal yang sangat penting dan tidak bisa lepas dari kehidupan individu, kelompok sosial maupun bangsa, karena pendidikan sesungguhnya memiliki misi yang amat mendasar yakni membentuk manusia seutuhnya dengan akhlak mulia sebagai salah satu indikator utamanya (Isnaini, 2013:445). Menurut UU No. 20 Tahun 2003 bab 2 pasal 3 dijelaskan bahwa pendidikan nasional berfungsi mengembangkan kemampuan dan membentuk watak serta peradaban bangsa yang bermartabat dalam rangka berkembangnya potensi peserta didik agar menjadi manusia yang bertaqwa dan beriman kepada Tuhan Yang Maha Esa, berakhlak mulia, sehat, berilmu, cakap, kreatif, mandiri dan menjadi warga negara yang demokratis, bertanggung jawab. (Amri, 2011:30)

Pendidikan pada saat ini dihadapkan pada tuntutan yang semakin komples dan beragam, hal itu sesuai dengan berkembangnya ilmu pengetahuan dan teknologi yang semakin maju. Kemajuan ilmu pengetahuan dan teknologi yang sangat pesat yang tidak di imbangi dengan pemberian materi pendidikan agama di sekolah dapat mengurangi nilai-nilai agama yang ada pada diri peserta didik, sehingga nilai-nilai agama yang sudah ada dalam diri peserta didik seolah-olah tidak digunakan dalam kehidupan sehari-hari. Melihat dari permasalahan tersebut, hal yang penting diperhatikan oleh lembaga pendidikan adalah menanamkan dan nilai-nilai agama kepada peserta didik, sehingga mereka tidak hanya memiliki kecerdasa intelektual saja, namun juga memiliki kecerdasan emosional dan spiritual sekaligus (Ansori, 2016:15).

Sekolah sebagai lembaga pendidikan menjadi wadah bagi anak untuk belajar memperoleh pengetahuan dan mengembangkan berbagai sikap, kemampuan, dan ketrampilan. Oleh karena itu, salah satu tujuan pendidikan di sekolah adalah untuk mengubah perilaku peserta didik. (Syukri, 2019:18) Sehubungan dengan hal itu, kehadiran madrasah sebagai salah satu lembaga pendidikan yang berbasis keagamaan dimana muatan nilai agama memiliki porsi yang cukup banyak diharapkan dapat membentuk pribadi dan mengembangkan karakter peserta didik sesuai dengan nilai agama. (Wiyani, 2012:14)

Nilai-nilai agama adalah nilai luhur yang ditransfer dan diadopsi ke dalam diri seseorang (Alim, 2004:10). Nilai-nilai agama mencakup tiga aspek, yaitu nilai akidah, nilai syariah dan nilai akhlak. Adanya internalisasi nilai-nilai agama di madrasah yang melibatkan aspek pengetahuan, perasaan, dan tindakan sangat diperlukan guna menumbuhkan kecerdasan secara emosinal maupun spiritual peserta didik. Melalui hal tersebut, diharapkan akan mendasari terciptanya suasana kehidupan keagamaan yang religius berdasarkan nilai-nilai agama di madrasah. Suasana religius di madrasah akan membentuk tradisi beragama di madrasah, yang pada akhirnya tradisi tersebut akan menjadi budaya, karakter, dan identitas dari madrasah.

Budaya religius merupakan salah satu wahana dalam menanamkan nilainilai agama kepada peserta didik (Fathurrahman, 2015:108). Budaya religius di lembaga pendidikan pada hakikatnya adalah terwujudnya nilai ajaran agama sebagai tradisi dalam berperilaku dan berbudaya organisasi yang diikuti oleh seluruh warga sekolah. Dengan menjadikan agama sebagai tradisi dalam sekolah, maka secara sadar maupun tidak sadar warga sekolah mengikuti tradisi 
yang telah tertanam tersebut sebenarnya warga sekolah sudah melakukan ajaran agama (Fathurrahman, 2015:51)

Wujud dari internalisasi nilai-nilai budaya religius di madrasah adalah dengan adanya kegiatan-kegiatan yang berbasis keagamaan, seperti shalat, berdoa, membaca Al-Qur'an, sholat berjamaah, dan lain sebagainya. Kegiatan keagamaan yaitu kegiatan yang berusaha memberi bantuan terhadap setiap individu agar dalam kehidupan keagamaannya senantiasa mencapai kebahagiaan dunia dan akhirat (Faqih, 2002: 62). Kegiatan keagamaan di madrasah dilakukan dengan proses yang terpola, terencana dan tersistematisasi dengan tujuan mampu menyentuh aspek afektif peserta didik sehingga mampu mempengaruhi EQ (Emotional Quotient) dan SQ (Spiritual Quotient). Selain itu, dengan internalisasi nilai-nilai budaya religius melalui kegiatan keagamaan pada peserta didik diharapkan dapat memperkokoh keimanan serta akan mempengaruhi sikap, sifat, dan tindakan peserta didik secara tidak langsung.

\section{Metode}

Penelitian ini merupakan penelitian dengan pendekatan kualitatif. Penelitian kualitatif adalah penelitian yang lebih menekankan analisisnya pada proses penyimpulan deduktif dan induktif serta analisis terhadap dinamika hubungan antar fenomena yang diamati dengan menggunakan logika ilmiah. (Mahmud, 2011,81) Sedangkan jenis penelitian yang digunakan adalah jenis penelitian studi kasus, yaitu penelitian yang dilakukan secara mendalam terhadap suatu organisasi atau lembaga tertentu untuk menemukan makna, menyelediki proses, dan memperoleh pengertian dan pemahaman yang mendalam dari kegiatan yang dilakukannya (Moleong, 2016: 6). Sementara metode pengumpulan datanya menggunakan metode observasi, wawancara dan dokumentasi. Sedangkan teknik analisis data menggunakan analisis model Miles dan Huberman dengan langkah-langkahnya yaitu mereduksi data, mendisplay data, dan menarik kesimpulan (Sugiyono, 2010: 337).

\section{Pembahasan}

\section{Internalisasi Nilai-Nilai Budaya Religius Melalui Kegiatan Keagamaan di MTsN 3 Ponorogo}

Nilai-nilai agama adalah nilai luhur yang ditransfer dan diadopsi ke dalam diri seseorang. Oleh karena itu, seberapa banyak dan seberapa jauh nilainilai agama bisa mempengaruhi dan membentuk sikap serta perilaku seseorang sangat bergantung dalam menginternalisasikan nilai-nilai agama ke dalam dirinya. Semakin dalam nilai-nilai agama yang terinternalisasi dalam diri seseorang, maka kepribadian, dan sikap religiusnya akan muncul dan terbentuk, sehingga nilai-nilai agama akan menjadi pusat dalam menyikapi segala sesuatu. (Alim, 2004:10)

Internalisasi adalah proses menanamkan dan menumbuh kembangkan suatu nilai atau budaya, agar nilai atau budaya tersebut menjadi bagian diri setiap orang. (Sahlan, 2011:74) Proses internalisasi terjadi melalui beberapa 
tahapan, yaitu: (a) menerima, (b) menanggapi, (c) memberi nilai, (d) mengorganisasi nilai, (e) karakterisasi nilai. Proses internalisasi nilai-nilai agama di sekolah yang dilakukan secara terprogam dan konsisten akan mendasari terciptanya suasana kehidupan yang religius di lingkungan sekolah/ madrasah. Penciptaan suasana religius dapat dimulai dengan mengadakan berbagai kegiatan keagamaan di lingkungan sekolah/madrasah. Karena apabila tidak diciptakan dan dibiasakan, maka budaya religius tidak akan terwujud. (Fathurrahman, 2015:108)

Budaya religius di lembaga pendidikan pada dasarnya adalah terwujudnya nilai ajaran agama sebagai tradisi dalam berperilaku dan berbudaya organisasi yang diikuti oleh seluruh civitas akademika. (Sahlan, 2011:50) Budaya religius di sekolah/ madrasah dapat diimplementasikan dalam bentuk kegiatan keagamaan yang didasari pada nilai-nilai ajaran Islam. Tujuan menanamkan budaya religius ini secara umum ditujukan kepada peserta didik yaitu agar peserta didik memiliki kekuatan spiritual keagamaan, pengendalian diri, kepribadian, kecerdasan, akhlak mulia, serta ketrampilan yang diperlukan dirinya, masyarakat, bangsa dan Negara.

Sebagai salah satu lembaga pendidikan Islam, wujud kepedulian MTsN 3 Ponorogo dalam menanamkan nilai-nilai budaya religius pada peserta didiknya yaitu mengembangkan budaya keislaman ke dalam kehidupan nyata peserta didik dengan cara mengaplisikannya dalam kegiatan keagamaan rutin yang diselenggarakan setiap harinya, yang terwujud dengan adanya salim sapa apabila bertemu dengan guru, melafalkan asmaul husna, kegiatan tartil AlQur'an, membaca asmaul husna, sholat dhuha dan sholat dzuhur berjamaah. Kegiatan yang dilakukan secara rutin mampu merasuk ke dalam intimintas jiwa seseorang dan akan ditanamkan dari generasi ke generasi.

Internalisasi nilai-nilai budaya religius melalui kegiatan keagamaan di MTsN 3 Ponorogo pada awalnya terbentuk karena adanya saran dan dukungan dari wali murid serta kebijakan dari kepala sekolah lewat tata tertib dan aturan yang berhubungan, dengan harapan adanya perubahan sikap dan perilaku peserta didik yang lebih baik dan benar, serta mengarahkan kesadaran peserta didik untuk menghayati nilai-nilai keagamaan sehingga mampu menjawab tantangan zaman.

Dalam menginternalisasikan nilai-nilai budaya religius melalui kegiatan keagamaan di MTsN 3 Ponorogo, dilakukan dengan beberapa strategi, seperti:

a. Pemberian hukuman (power strategi). Pemberian hukuman di berikan kepada peserta didik yang melanggar aturan yang ada di madrasah. Pemberian hukuman diharapkan dapat memberikan efek jera kepada peserta didik, sehingga peserta didik akan memiliki konsistensi sikap disiplin dan rasa tanggung jawab kedepannya.

b. Pembiasaan (persuasive strategy). Metode pembiasaan sangat praktis dalam pembinaan dan pembentukan karakter peserta didik, karena inti dari metode ini adalah pengulangan yang dilakukan setiap harinya.

c. Keteladanan (Normative re-education). Guru sebagai teladan bagi peserta didik ketika di madrasah harus memberikan contoh yang baik dalam 
ucapan maupun perbuatannya, sehingga peserta didik bisa merefleksikannya dalam kesehariannya.

Selain ketiga strategi yang digunakan di MTsN 3 Ponorogo dalam menginternalisasikan nilai-nilai budaya religius, menurut peneliti ada strategi lain yang bisa ditambahkan dalam menginternalisasikan nilai-nilai budaya religius kepada peserta didik yaitu:

a. Strategi pengalaman, dalam strategi ini proses penanaman nilai-nilai kepada peserta didik dilakukan dengan pemberian pengalaman secara langsung. Dengan strategi ini memberikan kesempatan kepada peserta didik untuk mendapatkan pengalaman secara spiritual baik secara individual maupun kelompok.

b. Strategi emosional, dengan strategi ini akan menggugah perasaan dan emosi peserta didik dalam menyakini konsep ajaran nilai-nilai universal serta dapat merasakan mana yang baik dan mana yang buruk.

c. Strategi rasional, dalam strategi ini peserta didik menggunakan akal (rasio) dalam memahami dan menerima kebenaran nilai-nilai universal yang diajarkan.

d. Strategi fungsional, dalam strategi ini menekankan pada penanaman nilai-nilai dari segi kemanfaatan bagi peserta didik dalam kehidupan sehari-hari, sesuai dengan tingkat perkembangannya (Muhtadi, 2007:67).

Internalisasi nilai-nilai budaya religius melalui kegiatan keagamaan di MTsN 3 Ponorogo selama ini sudah berjalan dengan baik, dengan memperhatikan tahapan dan kondisi dari peserta didik, hal itu tidak terlepas karena adanya kebijakan dari kepala sekolah yang terbentuk melalui skenario dari luar pelaku budaya yang bersangkutan atau yang disebut dengan pola pelakonan. Pola pelakonan yaitu terbentuknya budaya religius di sekolah/madrasah melalui penurutan, peniruan, penganutan, dan penataan (Sahlan, 2011:58).

Menurut peneliti dalam mengiternalisasikan nilai-nilai budaya religius dengan cara membiasakan peserta didik untuk melakukan praktek-praktek kegiatan keagamaan akan mendekatkan jiwa peserta didik kepada Tuhannya. Sebagaimana sesuai dengan tujuan dari kegiatan keagamaan yaitu menumbuhkan dan meningkatkan keimanan melalui pemberian dan pemupukan pengetahuan, penghayatan, serta pengamalan, sehingga menjadikannya manusia muslim yang terus berkembang dalam hal keimanan, ketaqwaannya kepada Allah SWT serta berakhlak mulia dalam kehidupan sehari-hari (Ancok, 2004:150).

Dari paparan diatas dapat disimpulkan bahwa penanaman nilai-nilai budaya religius melalui kegiatan-kegiatan yang ada di madrasah dengan menggunakan strategi yang tepat, akan berjalan secara baik, kondusif, serta menumbuhkan kesadaran beragama dalam diri peserta didik sekaligus meningkatkan kecerdasan emosional dan spiritual peserta didik.

Faktor Penghambat Dan Pendukung Internalisasi Nilai-Nilai Budaya Religius Melalui Kegiatan Keagamaan Di Mtsn 3 Ponorogo

Dalam suatu kegiatan tidak bisa terlepas dari adanya kendala yang dihadapi. Dalam konteks ini, internalisasi nilai-nilai budaya religius melalui 
kegiatan keagamaan di MTsN 3 Ponorogo juga menemui hal-hal yang mendukung sekaligus beberapa permasalahan yang menghambatnya.

Faktor penghambat dalam menginternalisasikan nilai-nilai budaya religius melalui kegiatan keagamaan di MTsN 3 Ponorogo adalah kurangnya kesadaran dari peserta didik, adanya pengaruh dari lingkungan pertemanan, serta kurangnya bimbingan agama dari orang tua. Sedangkan dukungan dari orang tua peserta didik dan keterlibatan guru secara langsung dan berperan aktif menjadi faktor pendukung dalam menginternalisasikan nilai-nilai budaya religius melalui kegiatan keagamaan di MTsN 3 Ponorogo.

Nilai religius memiliki peran yang penting dalam mewujudkan budaya religius. Penanaman nilai religius yang dilakukan sejak anak usia dini dengan bimbingan dan pendekatan dari keluarga secara terus menerus akan mengembangkan diri anak, sehingga anak akan mencapai pada tahap kematangan beragama dan menyadari pentingnya nilai religius dalam kehidupan (Yusuf, 2007:145). Internalisasi nilai budaya religius dipengaruhi oleh dua faktor yaitu faktor penghambat dan pendukung.

Faktor penghambat dalam penanaman nilai budaya religius diantaranya:

1. Budaya Globalisasi

Dalam upaya internalisasi nilai-nilai budaya religius dihadapkan pada budaya globalisasi yang merambah pada kehidupan peserta didik. Peserta didik akan sulit untuk menyadari nilai-nilai yang ditanamkan. Bahkan ada anak didik yang menentang apabila diingatkan untuk melaksanakan kegiatan religius.

2. Lingkungan Sekolah

Lingkungan sekolah merupakan tempat peserta didik bersosialisasi dengan teman sebayanya. Di lingkungan sekolah juga mempunyai dampak negatif dalam internalisasi nilai-nilai budaya religius diantaranya pengaruh dari teman sebaya, apabila ada satu anak yang malas mengikuti kegiatan secara tidak langsung teman yang lainnya juga ikut malas mengikuti kegiatan.

3. Orang Tua

Kurangnya pendidikan agama dari orang tua juga mempengaruhi internalisasi nilai-nilai budaya religius. Tidak adanya penguatan agama ketika anak berada di rumah menjadikan anak memiliki kesadaran beragama yang kurang.

Sedangkan untuk faktor pendukung dari penanaman nilai budaya religius diantaranya:

1. Orang Tua

Bentuk dukungan dari orang tua dalam penanaman nilai budaya religius adalah orang tua senantiasa mengingatkan dan mengawasi anaknya dalam menjalankan ibadah ketika di rumah.

2. Guru

Dalam melaksanakan kegiatan internalisasi nilai-nilai budaya religius, seorang pendidik harus melihat, merasakan, dan juga mempertimbangkan terhadap semua hal yang berkaitan dengan jalannya proses kegiatan tersebut. Karena sebuah kegiatan akan 
berjalan dengan baik, apabila memiliki faktor yang mendukung kegiatan tersebut, juga untuk meminimalisir seminimal mungkin hambatan yang ada guna mencapai tujuan yang ingin dicapai.

3. Peserta Didik

Adanya peserta didik yang sudah memiliki kesadaran beragama akan mempengaruhi peserta didik yang lainnya untuk memiliki kesadaran beragama.

Iklim madrasah yang kondusif dan keterlibatan dari semua guru menjadi faktor penentu kesuksesan penanaman nilai-nilai budaya religius melalui kegiatan keagamaan di MTsN 3 Ponorogo. Hal itu diperkuat dengan adanya bimbingan dan pengawasan yang diberikan guru kepada peserta didik dalam kegiatan keagamaan. Berdasarkan hal tersebut, maka keterlibatan guru disini sesuai dengan salah satu peran guru yaitu guru sebagai supervisor. Peran guru sebagai supervisor yaitu terkait dengan pemberian bimbingan dan pengawasan kepada peserta didik, memahami permasalahan yang dihadapi peserta didik, dan akhirmya memberikan jalan keluar pemecahan masalahnya (Suparlan, 2005:30).

Selain itu, ketersediaan sarana prasarana seperti masjid, sarana pendukung ibadah (seperti: tempat wudhu, kamar mandi, mukena dan mimbar) alat peraga prakek ibadah, dan ruang kelas belajar yang nyaman diyakini mampu menyampaikan nilai-nilai budya religius dengan baik kepada peserta didik.

Jika dilihat dari teori dan fakta yang ada di MTsN 3 Ponorogo, bisa ditarik kesimpulan diantara keduanya bahwa latar belakang orang tua memiliki peran penting dalam penanaman nilai budaya religius kepada diri peserta didik. Antusiasme peserta didik dalam kegiatan pembiasaan penanaman nilai budaya religius serta upaya dan dukungan yang diberikan guru dalam menanamkan nilai budaya religius di madrasah menjadi faktor penentu dalam keberhasilan jalannya internalisasi nilai-nilai tersebut. Agar penanaman nilai budaya religius tersebut berjalan dengan lancar, maka diperlukan dukungan dan kerja sama yang baik dari semua pihak. Dengan adanya kerja sama dari semua pihak tersebut, akan memudahkan dalam melakukan pengawasan dan evaluasi.

\section{Pengaruh internalisasi nilai-nilai budaya religius melalui kegiatan keagamaan di MTsN 3 Ponorogo}

Penanaman nilai-nilai budaya religius dilakukan dengan menciptakan suasana yang memungkinkan untuk terinternalisasinya nilai-nilai budaya religius dalam diri peserta didik (Naim, 2012:125). Internalisasi dapat dilakukan dengan memberikan pemahaman tentang agama kepada peserta didik, terutama tentang tanggung jawab manusia sebagai pemimpin yang arif dan bijaksana, dan mereka diharapkan memiliki pemahaman agama yang inklusif dan tidak ekstrim. Selanjutnya, senantiasa diberikan nasehat kepada peserta didik tentang adab bertutur kata yang sopan dan bertata krama yang baik terhadap orang tua, guru maupun dengan orang lain.

Adanya tata nilai-nilai budaya religius di madrasah diharapkan mampu membentuk sikap dan perilaku-perilaku warga madrasah yang religius. Nilainilai budaya religius yang diaktualisasikan oleh setiap individu warga madrasah juga diharapkan dapat memproduksi warga madrasah yang religius secara 
stimulan melalui proses tahapan pemahaman, pengendapan, dan penciptaan pribadi yang islami. Ketiga proses tersebut akan berlangsung secara turun temurun di dalam kehidupan sosial madrasah.

Berdasarkan data di lapangan, internalisasi nilai-nilai budaya religius di MTsN 3 Ponorogo melalui kegiatan keagamaan telah memberikan pengaruh kepada peserta didik, antara lain yaitu:

a. Peningkatan kedisiplinan peserta didik dalam hal apapun

Kegiatan membaca Al-Qur'an mengajarkan kepada peserta didik untuk mencintai Al-Qur'an dan wujud ibadah kepada Allah. Selain itu juga sebagai upaya untuk meningkatkan kedisiplinan peserta didik. Hal itu dikarenakan jika peserta didik belum datang dan belum masuk kelas sebelum kegiatan berlangsung, maka mereka akan mendapatkan hukuman dari guru yang membimbing kegiatan membaca Al-Qur'an sesuai dengan kelasnya masing-masing. Dengan adanya pemberian hukuman tersebut, lambat laun akan tertanam sikap disiplin pada peserta didik, terutama dalam hal disiplin waktu.

b. Peningkatan kesadaran beribadah

Kesadaran dalam beribadah tersebut dapat dilihat dari perilaku peserta didik. Yakni, ketika jadwal waktu shalat dhuha yang dilakukan secara bergantian, peserta didik bergegas ke masjid. Begitu juga ketika masuk waktu shalat dzuhur, mereka lekas berangkat ke masjid setelah adzan berkumandang. Dengan adanya pembiasaan shalat dhuha dan shalat dzuhur berjamaah, pelan-pelan namun pasti kebiasaan itu akan merasuk ke dalam diri peserta didik dan berdampak juga terhadap kesadaran beribadah peserta didik baik di madrasah maupun di lingkungan tempat tinggal.

c. Peningkatan sikap sosial dan sikap kerukunan peserta didik

Sebagai figur teladan bagi peserta didiknya, seorang pendidik disekolah ini selalu memberikan contoh perilaku dan sikap yang baik. Karena itu, guru-guru di sini menjadi panutan bagi peserta didik untuk mencontohnya. Salah satu yang dicontohkan pendidik di sini selalu member salam dan menyapa orang lain yang dijumpainya. Sikap saling sapa ini kemudia ditanamkan melalui kegiatan salim sapa dan dibudayakan di sekolah sehari-hari. Karena kegiatan ini, kerukunan dan sikap sosial di sekolah ini menjadi terbangun solid. Tidak hanya melalui kegiatan salim sapa, kerukunan yang solid ini sesungguhnya juga terbangun karena peserta didik sering melakukan solat berjamaah bersama di masjid untuk menunaikan solat dhuha dan solat dzuhur.

Berdasarkan penjelasan diatas, dapat dikatakan bahwa kegiatan keagamaan merupakan wahana yang digunakan untuk mentransfer nilai-nilai religius kepada peserta didik. Sebagaimana pendapat Muhaimin, Salah satu fungsi dari budaya religius adalah menstransfer nilai kepada peserta didik. Tanpa adanya budaya religius, maka pendidik akan kesulitan dalam menstranfer nilai-nilai tersebut, karena menstransfer nilai tersebut tidak cukup hanya mengandalkan pembelajaran di kelas saja. (Fathurrahman, 2015:104) 
Menurut peneliti internalisasi nilai-nilai budaya religius di madrasah tidak hanya ditujukan kepada peserta didik saja, namun semua warga madrasah harus ikut terlibat didalamnya. Keterlibatan semua warga madrasah dalam mengikuti kegiatan keagamaan, akan mendorong peserta didik untuk memiliki keteraturan dalam kesehariannya, mampu mengontrol dirinya dalam bersikap dan bertanggung jawab, serta memiliki karakter yang baik. Hal itu sesuai manfaat kegiatan keagamaan yaitu menerangkan, memprediksi ataupun mengontrol terutama mengarahkan manusia untuk mencapai ridha-Nya. (Ancok, 2004:150)

\section{Kesimpulan}

Berdasarkan temuan hasil penelitian tentang internalisasi nilai-nilai budaya religius melalui kegiatan keagamaan di MTsN 3 Ponorogo, dapat disimpulkan bahwa:

1. Internalisasi nilai-nilai budaya religius di MTsN 3 Ponorogo dilakukan melalui kegiatan salim sapa, melafalkan asmaul husna, kegiatan tartil AlQur'an, serta sholat dhuha dan sholat dzuhur berjamaah.

2. Faktor penghambat dalam menginternalisasikan nilai-nilai budaya religius melalui kegiatan keagamaan di MTsN 3 Ponorogo adalah kurangnya kesadaran dari peserta didik, adanya pengaruh dari lingkungan pertemanan, serta kurangnya bimbingan agama dari orang tua. Sedangkan dukungan dari orang tua peserta didik dan keterlibatan guru secara langsung dan berperan aktif menjadi faktor pendukung dalam menginternalisasikan nilai-nilai budaya religius melalui kegiatan keagamaan di MTsN 3 Ponorogo.

3. Pengaruh internalisasi nilai-nilai budaya religius melalui kegiatan keagamaan di MTsN 3 Ponorogo, antara lain yaitu: meningkatnya kedisiplinan peserta didik dalam hal apapun terutama dalam segi kedisiplinan waktu, meningkatnya kesadaran peserta didik dalam hal beribadah, dan meningkatnya sikap sosial dan sikap kerukunan peserta didik dengan lingkungan. Selain itu, akan mendorong peserta didik untuk memiliki keteraturan dalam kesehariannya, mampu mengontrol dirinya dalam bersikap dan bertanggung jawab, serta memiliki karakter yang baik. 


\section{Daftar Pustaka}

Alim, Muhammad. Pendidikan Agama Islam. Bandung: PT. Remaja Rosdakarya, 2004.

Amri, Sofan. Implementasi Pendidikan Karakter Dalam Pembelajaran. Jakarta: Prestasi Pustaka, 2011.

Ancok, Djamaluddin dan Fuad Nashori Suroso, Psikologi Islami Solusi Islam Atas Problem-Problem Psikologi. Yogyakarta: Pustaka Pelajar Offset, 2004.

Ansori, Raden Ahmad Muhajir. "Strategi Penanaman Nilai-Nilai Pendidikan Islam Pada Peserta Didik," Jurnal Pusaka LP3M IAI Al-Qolam, (2016), 15.

Faqih, Aunur Rahim. Bimbingan Konseling dalam Islam, Yogyakarta: UII Press, 2001.

Fathurrahman, Muhammad. Budaya Religius dalam Mutu Pendidikan: Tinjauan Teoritik dan Praktik Kontekstual Pendidikan Agama di Sekolah, Yogyakarta: Kalimedia, 2015.

Isnaini, Muhammad. Internalisasi Nilai-Nilai Pendidikan Karakter Di Madrasah. Jurnal Al-Ta'lim, Jilid 1, Nomor 6 November 2013.

Moloeng, Lexy. Metodologi Penelitian Kualitatif. Bandung: PT Remaja Rosdakarya, 2016.

Mahmud, Metode Penelitian Pendidikan. Bandung: Pustaka Setia, 2011.

Muhtadi, Ali. Teknik dan Pendekatan Penanaman Nilai Dalam Proses Pembelajaran di Sekolah. Majalah Ilmiah Pembelajaran Nomor, I, Vol, 3 (Mei 2007). 67.

Naim, Ngainun. Charakter Building. Yogjakarta: Ar-Ruzz Media, 2012.

Sahlan, Asmaun. Religiusitas Perguruan Tinggi: Potret Pengembangan Tradisi Keagamaan Di Perguruan Tinggi Islam, Malang: UIN Maliki Press, 2011.

Sugiono, Metode Penelitian Pendidikan Pendidikan Pendekatan Kuantitatif, Kualitataif, dan RED, Bandung: Alfabeta, 2010.

Sukmadinata, Nana Syaodih. Metode Penelitian Pendidikan. Bandung: PT Remaja Rosdakarya, 2009.

Suparlan, Menjadi Guru Efektif. Yogyakarta: Hikayat Publishing, 2005.

Syukri, Icep Irham Fauzan dkk. "Pengaruh Kegiatan Keagamaaan Terhadap Kualitas Pendidikan". Jurnal Penelitian Pendiidkan Islam VOL 7 No 1, 2019.

Wiyani, Novan Ardy. Pendidikan Karakter Berbasis Iman dan Taqwa. Yogyakarta: Teras, 2012.

Yusuf, Syamsul. Psikologi Perkembangan Anak dan Remaja, Bandung: PT Remaja Rosdakarya, 2007. 